\title{
KEEFEKTIFAN LEMBAR KERJA SISWA BERBASIS INKUIRI UNTUK MENUMBUHKAN KETERAMPILAN BERPIKIR TINGKAT TINGGI
}

\author{
Dian Purnamawati ${ }^{1}$, Chandra Ertikanto ${ }^{2}$, Agus Suyatna $^{3}$ \\ ${ }_{1,2,3}$ Magister Pendidikan Fisika, Universitas Lampung, Indonesia \\ e-mail: dianpurnamawati90@gmail.com
}

Diterima: 12 Maret 2017. Disetujui: 21 September 2017. Dipublikasikan: 28 Oktober 2017

\begin{abstract}
Abstrak: Penelitian ini bertujuan untuk mengetahui keefektifan LKS berbasis inkuiri untuk menumbuhkan keterampilan berpikir tingkat tinggi pada materi suhu dan kalor. Desain yang digunakan pada penelitan ini One group pretest posttest design. Teknik analisis data dilakukan dengan menggunakan uji N-gain dan one sampel t-test. Hasil penelitian menunjukkan LKS ini dinyatakan efektif sebagai inovasi pembelajaran berdasarkan indikator keterampilan berpikir tingkat tinggi yaitu menganalisis (C4) dan mencipta (C6) masuk dalam kategori tinggi dengan $\mathrm{N}$-gain 0,70 sedangkan untuk mengevaluasi diperoleh diperoleh $\mathrm{N}$ gain 0,72. Efektivitas LKS berbasis keterampilan berpikir tingkat tinggi terbukti berpengaruh untuk menumbuhkan keterampilan berpikir tingkat tinggi berdasarkan perolehan hasil menggunakan effect size sebesar 0,6 untuk menganalisis dan mengevaluasi sedangkan untuk mencipta 0,7.
\end{abstract}

Kata kunci: Inkuiri, keterampilan berpikir tingkat tinggi, LKS.

\section{THE EFFECTIVENESS OF INQUIRY-BASED STUDENT WORKSHEETS TO IMPROVE THE HIGHER-ORDER THINKING SKILLS}

\begin{abstract}
This research is intended to know the effectiveness of worksheet based on an inquiry to grow the higher order thinking on temperature and heat. The design which is used in this research is one group pretest-posttest design. The data analysis technique was performed by using the $N$-gain test and one sample t-test. The result of this research shows that Student Worksheet is effective as learning innovation based on high level thinking the skill that is analyzing (C4) and creating (C6) into a high category with $N$ gain 0,70 while to evaluate obtained N-gain 0,72 (height). Student Worksheet effectiveness based on highlevel thinking skill proved influential in cultivating high-level thinking skills based on the results obtained using effect size of 0.6 to analyze and evaluate while to create 0.7 .
\end{abstract}

(C) 2017 Pendidikan Fisika, FTK UIN Raden Intan Lampung

Keywords: Inquiry, higher order thinking skills, students' worksheet.

\section{PENDAHULUAN}

Pendidikan merupakan faktor yang sangat penting untuk menunjang serta menjamin siswa memiliki keterampilan belajar dan berinovasi, keterampilan menggunakan teknologi dan media informasi, serta dapat bekerja, dan bertahan dengan menggunakan keterampilan untuk hidup (life skills) (Arifin, 2017). Pada abad 21 pembelajaran fisika memiliki tujuan $4 \mathrm{C}$, yaitu; Communication, Collaboration, Critical Thinking and Problem Solving,
Creativity and Innovation (National Education Association, 2014). Selain itu Badan Standar Nasional Pendidikan (BNSP, 2006; Wati \& Fatimah, 2016) menyatakan salah satu tujuan pembelajaran fisika di sekolah adalah mengembangkan kemampuan bernalar dalam berpikir analisis induktif dan deduktif dengan menggunakan konsep dan prinsip fisika untuk menjelaskan berbagai peristiwa alam dan menyelesaikan masalah baik secara 
kualitatif maupun kuantitatif. Dalam mempelajari fisika tidak dapat dengan langsung mempelajari produknya saja akan tetapi diperlukan suatu kegiatan pembelajaran yang melibatkan siswa dalam suatu proses pemecahan masalah atau eksperimen untuk menghasilkan suatu produk (Erlinda, 2016). Melalui pembelajaran dengan model inkuiri siswa mampu mengembangkan keterampilan berpikir tingkat tinggi. Menurut penelitian Lailly \& Wisudawati, HOTS (Higher Order Thinking Skill) meliputi aspek kemampuan berpikir kritis, kemampuan berpikir kreatif, dan kemampuan memecahkan masalah. (Lailly \& Wisudawati, 2015; Lindawati, Saregar, \& Yuberti, 2016). Keterampilan berpikir juga dapat diasah dengan pembelajaran diskusi maupun berbasis research (Rohaniawati, 2016)

Keterampilan berpikir tingkat tinggi (HOT) siswa dapat membedakan ide atau gagasan secara jelas, berargumen dengan baik, mampu memecahkan masalah, mampu mengkonstruksi penjelasan, mampu berhipotesis dan memahami halhal kompleks menjadi lebih jelas (Widodo \& Kadarwati, 2013) Agar tujuan pembelajaran fisika pada abad 21 tercapai diperlukan bahan ajar yang sesuai dengan kondisi saat ini seperti LKS.

Penelitian Özmen \& Yildirim menunjukkan bahwa bahan ajar LKS lebih efektif dibandingkan metode dan bahan ajar tradisional. LKS memiliki banyak manfaat dalam prestasi akademik (Özmen \& Yildrim, 2005). Misalnya, sebagai tambahan untuk buku teks, lembar kerja juga dapat digunakan untuk menambahkan informasi (Lee, 2014).

LKS dapat membantu siswa memahami materi dan memberi kesempatan luas untuk mendemonstrasikan pengetahuan dan mengembangkan keterampilan proses (Karsli \& Şahin, 2009; Saregar, 2016). LKS dapat meningkatkan pembelajaran sukses dan membuat siswa lebih aktif dan efisien dalam belajar(Trewet \& Fjortoft, 2013).

LKS dapat mengembangkan kemampuan berpikir kreatif (Susantini, Isnawati, \& Lisdiana, 2016). Dalam penelitiannya Crespo \& Pozo menyatakan bahwa penggunaan lembar kerja dalam pembelajaran dapat meningkatkan pengalaman belajar siswa (Crespo \& Pozo, 2004).

LKS berbasis inkuiri melibatkan siswa lebih aktif dalam melakukan proses pembelajaran. Dalam konteks pembelajaran berbasis inkuiri (inquirybased learning), fase-fase kegiatan penyelidikan ilmiah menggunakan sejumlah tools laboratorium akan meningkatkan proses aktivitas saintifik siswa (Abdurrahman, 2016) (Abdurrahman, 2016; Akpan dan Strayer, 2010).

LKS berbasis inkuiri merupakan model pembelajaran yang melatih siswa untuk belajar menemukan masalah, mengumpulkan, mengorganisasikan, dan memecahkan masalah (Kristianingsih, 2010). Serupa dengan penelitian Konstelnikova \& Ozvoldova, tahapan pembelajaran dengan model inkuiri merupakan tahapan yang membantu siswa memiliki keterampilan berpikir tingkat tinggi dimana siswa akan menggunakan logika, berpikir kreatif dan membangun pengetahuan siswa yang akhirnya memotivasi siswa dalam proses pembelajaran (Kostelníková \& Ožvoldová, 2013). Selain itu kemampuan berpikir tingkat tinggi dapat dilatih melalui kegiatan merumuskan masalah, membuat hipotesis, kegiatan presentasi yang dapat memfasilitasi peserta didik untuk melakukan kegiatan tanya jawab, dan mengevaluasi proses pencarian solusi permasalahan (Yonata, Khofifatin, 2013). Hal ini serupa dengan indikator keterampilan berpikir tingkat tinggi yaitu: menganalisa, sintesis, dan evaluasi (Hopson, Simms, \& Knezek, 2001). 
Pelaksanaan LKS berbasis inkuiri dapat optimal, peran guru sangat penting dalam pembelajaran inkuiri apabila seseorang guru yang mempunyai kemampuan inkuiri akan memberikan kontribusi yang tinggi terhadap pelaksanaan (Ertikanto, 2014). Proses pembelajaran secara inkuiri tidak akan tercapai apabila guru tidak mempunyai pengetahuan tentang inkuiri, terungkap pula bahwa pembelajaran secara inkuiri menjadi standar secara internasional yang harus digunakan dalam pembelajaran sains (Ertikanto, 2014).

Salah satu materi fisika yang memerlukan pemahaman konsep dan keterampilan berpikir tingkat tinggi adalah materi suhu dan kalor. Materi suhu dan kalor sangat erat kaitannya dengan mata pelajaran produktif di SMK kesehatan dimana siswa diajarkan mengukur suhu tubuh, mengkonversi suhu. Pada kegiatan pembelajaran ini keterampilan berpikir tingkat tinggi siswa dapat ditumbuhkan melalui model inkuiri.

Perbedaan penelitian ini dengan penelitian yang sudah ada adalah LKS materi suhu dan kalor dengan model inkuiri berisi materi yang berkaitan dengan mata pelajaran produktif di SMK Kesehatan diharapkan dapat memberikan hasil yang baik dalam proses belajar, terhadap keterampilan berpikir tingkat tinggi siswa.

\section{LANDASAN TEORI}

Menurut (Yusuf hadi, 2004), pembelajaran adalah yang menghasilkan belajar yang bermanfaat dan bertujuan bagi para siswa, melalui prosedur pembelajaran yang tepat.Pada penelitian ini mengukur efektivitas LKS dengan model inkuiri berbasis keterampilan berpikir tingkat tinggi siswa pada materi suhu dan kalor.

LKS merupakan salah satu bahan ajar yang penting untuk tercapainya keberhasilan dalam pembelajaran fisika (Damayanti, Ngazizah, \& Setyadi K,
2013). Menurut (Trianto, 2010) adalah panduan siswa yang digunakan untuk melakukan kegiatan penyelidikan atau pemecahan masalah. Lembar kegiatan ini dapat berupa panduan untuk latihan pengembangan aspek kognitif maupun panduan untuk pengembangan semua aspek pembelajaran dalam bentuk panduan eksperimen atau demonstrasi. LKS ini menggunakan model inkuiri pada tahapan pembelajarannya. Inkuiri berasal dari bahasa Inggris inqury yang dapat diartikan sebagai proses bertanya dan mencari tahu jawabanterhadap pertanyaan ilmiah yang diajukan. Strategi pembelajaran inkuiri adalah rangkaian kegiatanpembelajaran yang menekankan pada proses berpikir secara kritis dan analitis untuk mencari dan menemukan jawaban dari suatu masalah yang dipertanyakan. Proses pembelajaran dengan inkuiri mengikuti langkahlangkah (Trianto, 2010):

1. Mengajukan Pertanyaan atau Permasalahan Kegiatan inkuiri dimulai ketika pertanyaan atau permasalahan diajukan.

2. Merumuskan Hipotesis

Hipotesis adalah jawaban sementara atas pertanyaan atau solusi permasalahan yang dapat diuji dengan data.

3. Mengumpulkan Data

Hipotesis digunakan untuk membantu proses pengumpulan data. Data yang dihasilkan dapat berupa tabel, metrik, atau grafik.

4. Analisis Data

Siswa bertanggung jawab menguji hipotesis yang telah dirumuskan dengan menganalisis data yang diperoleh. Setelah memperoleh kesimpulan dari data percobaan, siswa dapat menguji hipotesis yang telah dirumuskan. Jika hipotesis itu salah atau ditolak maka siswa dapat menjelaskan sesuai dengan proses inkuiri yang telah dilakukannya. 
5. Membuat Kesimpulan

Langkah penutup dari pembelajaran inkuiri adalah membuat kesimpulan sementara berdasarkan data yang diperoleh siswa.

Kemampuan berpikir tingkat tinggi didefinisikan sebagai penggunaan pikiran secara lebih luas untuk menemukan tantangan baru (Rofiah, Aminah, \& Ekawati, 2013). Kemampuan berpikir kritis dan berpikir kreatif merupakan indikator kemampuan berpikir tingkat tinggi (Jayanti, Romlah, \& Saregar, 2016). Pengembangan berpikir kritis dan berpikir kreatif tidak akan terlepas dari pengembangan kemampuan kinerja otak kiri dan otak kanan yang membutuhkan latihan yang berlanjut yang dapat dilakukan melalui pembelajaran semua bidang studi di sekolah. Berpikir kritis merupakan salah satu proses berpikir tingkat tinggi yang dapat digunakan dalam pembentukan sistem konseptual siswa. Yuliati menyatakan dalam penelitiannya kemampuan berpikir tingkat tinggi mencakup kemampuan dalam cakupan dimensi proses menerapkan, menganalisis, mengevaluasi dan menciptakan dengan dasar-dasar proses mengingat dan memahami yang baik (Yuliati, 2013). Inti urutan berpikir lebih tingkat tinggi terdapat pada mensintesis dan evaluasi. (Rustaman, 2011). Dimana dapat dilihat pada Tabel 1 tingkatan berpikiri tingkat tinggi.

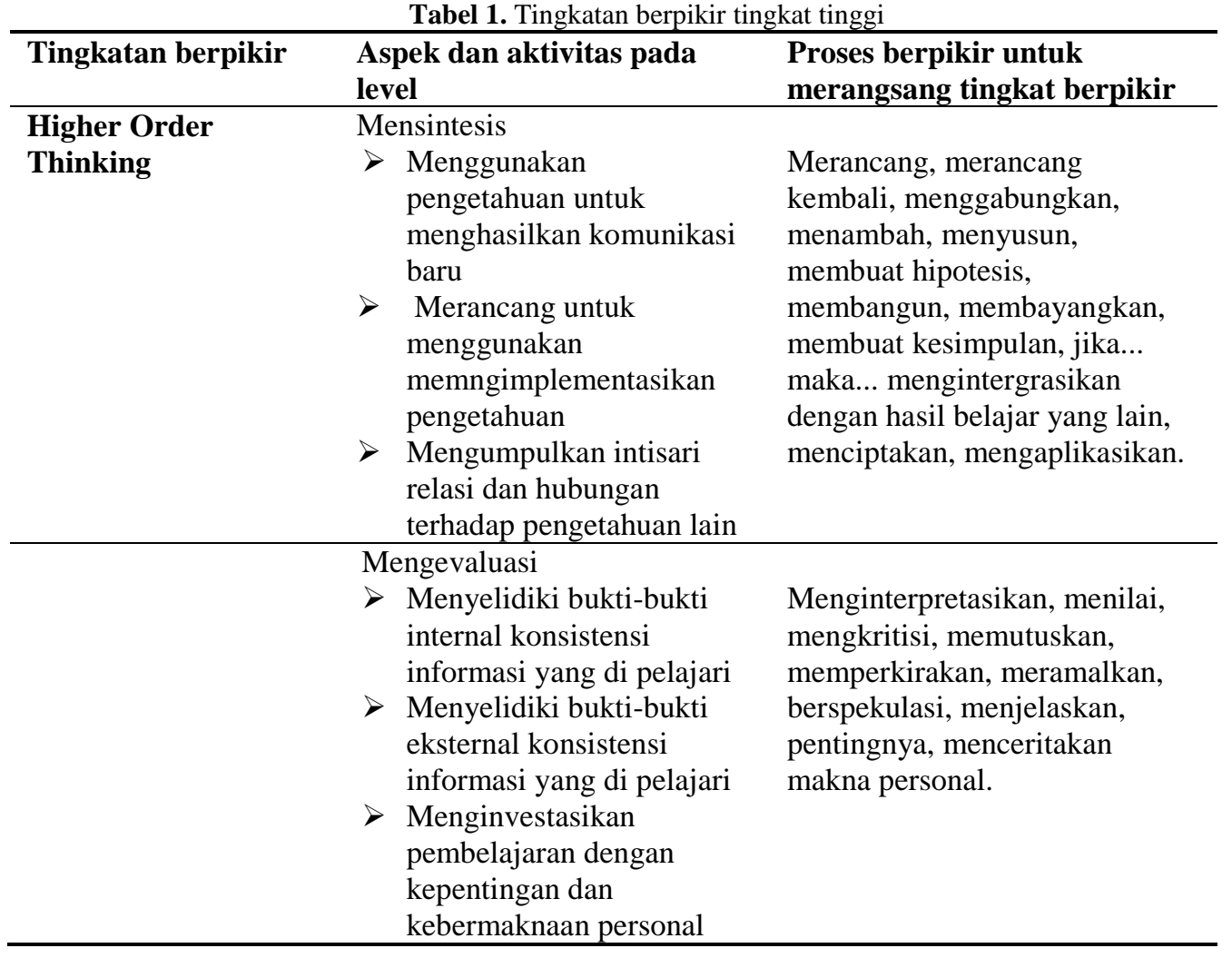

\section{METODELOGI PENELITIAN}

Desain penelitian ini menggunakan One group pretest posttest design, (Gambar 1) (Sugiyono, 2010).

$$
\begin{array}{lll}
\mathrm{O}_{1} & \mathrm{X} & \mathrm{O}_{2}
\end{array}
$$

Gambar 1Desain eksperimen
Keterangan:

$\mathrm{O}_{1}=$ Pretes

$\mathrm{O}_{2}=$ Postest

$\mathrm{X}=$ Perlakuan/ treatment yang diberikan (variabel independen)

Penelitian in dilaksanakan di SMK YPIB Kotabumi tahun ajaran 2016/2017. Sampel terdiri dari satu kelas eksperimen 
dengan jumlah 24 orang tanpa kelas pembanding.

Keefektifan LKS berbasis inkuri untuk menumbuhkan keterampilan berpikir tingkat tinggi diuji dengan Uji ( $N$-gain). Uji $N$-gain digunakan untuk mengetahui besar peningkatan keterampilan berpikir tingkat tinggi siswa pada saat sebelum dan setelah diberikan perlakuan. Menggunakan rumus sebagai berikut: (Hake, 2002)

$$
N \text {-Gain }=\frac{\bar{X} \text { post }-\bar{X} \text { pre }}{\bar{X} \max -\bar{X} \text { pre }}
$$

Tabel 2 Kriteria N-gain

\begin{tabular}{cc}
\hline $\boldsymbol{N}$-gain & Kriteria \\
\hline$N$-gain $\leq 0,3$ & Rendah \\
$0,7 \geq N$-gain $>0,3$ & Sedang \\
$N$-gain $>0,7$ & Tinggi \\
\hline
\end{tabular}

Setelah menguji nilai $N$-gain maka dilakukan Uji One Sampel t-tes. Uji One Sampel t-tes digunakan untuk mengetahui nilai efektifitas menggunakan LKS lebih besar dari $N$-gain atau sama dengan $N$ gain pada kriteria tertentu. Selain itu untuk melihat keefektifan penerapan model inkuiri terhadap keterampilan berpikir tingkat tinggi dapat menggunakan effect size. Effect size dapat dihitung dengan formulasi (d) sebagai berikut (Wykes et al., 2011)

$$
d=\frac{(\mathrm{MI}-\mathrm{MB})}{\mathrm{SDP}}
$$

dengan,
$\mathrm{SDP}=\sqrt{S_{1}^{2}+S_{2}^{2}-2 r S_{1}} S_{2}$

Keterangan:

$\mathrm{d}=$ effect size

$M I=$ rata-rata post-test

$M B=$ rata-rata pre-test

$S D P=$ standar deviasi pooled

$S_{1}=$ Simpangan baku pretest

$\mathrm{S}_{2}=$ Simpangan baku posttest

$\mathrm{r}=$ Korelasi

(Saregar, Latifah, \& Sari, 2016), Cohen (1998) mengatakan bahwa nilai effect size 0,20 berarti berpengaruh kecil; 0,50 berpengaruh sedang; dan 0,80 berpengaruh besar. Secara lebih terperinci, kategori nilai effect size dapat dilihat dari Tabel 3 berikut.

Tabel 3. Kategori nilai effect size

\begin{tabular}{cc}
\hline Effect Size & $\begin{array}{c}\text { Tingkat } \\
\text { Hubungan }\end{array}$ \\
\hline $\mathrm{d}<0,2$ & Rendah \\
\hline $0,2<\mathrm{d}<0,8$ & Sedang \\
\hline $\mathrm{d}>0,8$ & Tinggi \\
\hline
\end{tabular}

\section{HASIL DAN PEMBAHASAN}

Hasil analisis data penggunaan LKS dengan model inkuiri dapat menumbuhkan keterampilan berpikir tingkat tinggi siswa, terlihat dari kemampuan awal dan kemampuan akhir siswa mengalami peningkatan berdasarkan $N$-gain dan one sampel t-test pada setiap indikator. Hasil pencapaian berpikir tingkat tinggi secara lengkap dapat dilihat pada tabel 4 .

Tabel 4. Hasil pencapaian berpikir tingkat tinggi siswa

\begin{tabular}{lllllllll}
\hline No & Indikator KBTT & Dretest & Posttest & Peningkatan & $\boldsymbol{N}$-gain & Value & $\mathbf{P}$ & Kategori \\
\hline $\mathbf{1}$ & Menganalisis & 23,13 & 77,92 & 54,79 & 0,70 & 0,7 & 0,000 & Tinggi \\
\hline $\mathbf{2}$ & Mengevaluasi & 22,29 & 78,75 & 56,46 & 0,72 & 0,7 & 0,000 & Tinggi \\
\hline $\mathbf{3}$ & Mencipta & 19,58 & 76,87 & 57,29 & 0,70 & 0,7 & 0,000 & Tinggi \\
\hline
\end{tabular}

Effect size digunakan sebagai ukuran mengenai tingkat keberhasilan dalam penelitian (Huck, 2012; Saregar et al.,
2016). Keefektifan LKS berbasis inkuiri terhadap keterampilan berpikir tingkat 
tinggi menggunakan effect size diperoleh pada tabel 5 sebagai berikut.

Tabel 5. Hasil effect size

\begin{tabular}{llclll}
\hline No & $\begin{array}{l}\text { Indikator } \\
\text { KBTT }\end{array}$ & Dretest & Posttest & $\begin{array}{l}\text { Effect } \\
\text { size (d) }\end{array}$ & Kategori \\
\hline $\mathbf{1}$ & Menganalisis & 23,13 & 77,92 & 0,6 & Sedang \\
\hline $\mathbf{2}$ & Mengevaluasi & 22,29 & 78,75 & 0,6 & Sedang \\
\hline $\mathbf{3}$ & Mencipta & 19,58 & 76,87 & 0,7 & Sedang \\
\hline
\end{tabular}

Berdasarkan tabel 4, diketahui bahwa keterampilan berpikir tingkat tinggi awal siswa masih dalam kategori rendah pada semua indikator. Hal ini menunjukkan bahwa keterampilan berpikir tingkat tinggi siswa masih kurang dilatih. Siswa belum terbiasa melakukan langkahlangkah berpikir tingkat tinggi. Setelah diberikan perlakuan menggunakan LKS berbasis inkuiri semua indikator keterampilan berpikir tingkat tinggi seperti menganalisis (C4), mengevaluasi (C5), dan Mencipta (C6) mengalami peningkatan dan $N$-gain masing-masing indikator masuk dalam kategori tinggi. Selanjutnya hasil uji hipotesis statistik menggunakan one sampel t-test diperoleh nilai Sig (p) dari ketiga indikator sebesar $0,000<0,05$, maka dapat disimpulkan bahwa secara signifikan nilai post-test setelah menggunakan LKS lebih tinggi dari nilai pre-test sebelum menggunakan LKS.

Berikut adalah grafik hasil pencapaian berpikir tingkat tinggi siswa secara detail terlihat pada gambar 2 .

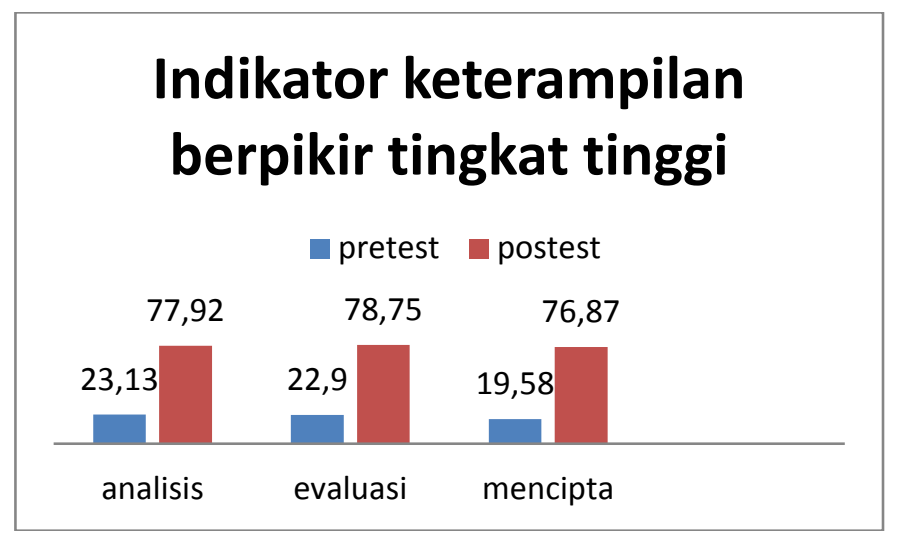

Gambar 2. Grafik hasil pencapaian berpikir tingkat tingg

Gambar 3 merupakan Grafik hasil pencapaian berpikir tingkat tinggi siswa.Pada tabel 3 hasil perolehan effect size menunjukkan sedang pada ketiga indikator berpikir tingkat tinggi. Hal ini menunjukkan bahwa LKS berbasis Inkuiri efektif terhadap keterampilan berpikir tingkat tinggi siswa pada materi suhu dan kalor.Tahapan kegiatan menggunakan model inkuiri fase pertama merumuskan masalah, siswa diberi kesempatan untuk mengembangkan gagasan berpikirnya dengan cara mengajukan rumusan masalah dari gambaran atau fenomena yang disajikan dalam LKS sebagai hipotesis awal penelitian. Hal ini termasuk dalam indikator menganalisis pada keterampilan berpikir tingkat tinggi. 
Berdasarkan grafik hasil pencapaian berpikir tingkat tinggi siswa, indikator menganalisis telah terpenuhi dengan skor $\mathrm{N}$-gain 0,70 kategori tinggi. Berikut ini adalah contoh hasil jawaban siswa dari fenomena yang disajikan.

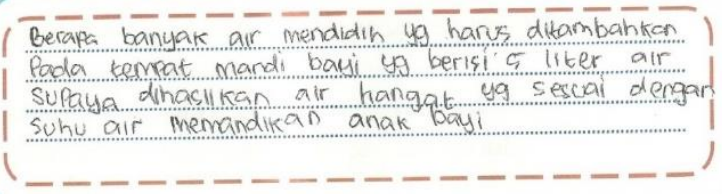

Gambar 4. Rumusan Masalah

Selanjutnya fase kedua siswa diberi kesempatan menuliskan gagasan berpikirnya melalui dugaan sementara contoh hasil hipotesis siswa sebagai berikut:

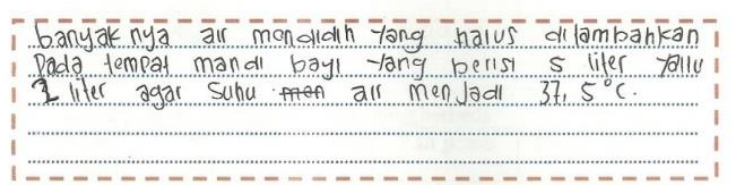

Gambar 5. Hipotesis siswa

Fase ketiga yaitu mengumpulkan data dan fase keempat analisis data, pada fase ini siswa mempersiapkan dan merancang eksperimen untuk mencoba menjawab rumusan masalah. Keaktifan berpikir tingkat tinggi terlihat dari keaktifan siswa dalam berpikir kritis dan berpikir kreatif terlihat pada kegiatan ayo bereksperimen sesuai dengan indikator keterampilan berpikir tingkat tinggi yaitu mencipta, Siswa dilatih dengan pertanyaan agar dapat menganalisis, mengevaluasi, menyelesaikan masalah, menghasilkan karya dan pengambilan keputusan (Suryawati, Hamzah, \& Hayati, 2015). Berdasarkan tabel di atas indikator mencipta telah mengevaluasi telah terpenuhi dengan $\mathrm{N}$-gain 0,70 (tinggi).

Fase kelima yaitu membuat kesimpulan, sesuai dengan indikator keterampilan berpikir tingkat tinggi yaitu mengevaluasi. Fase ini terpenuhi dengan $\mathrm{N}$-gain 0,72 kategori tinggi, terlihat dari laporan hasil penemuan yang telah dilakukan masing-masing kelompok yang disampaikan dalam kegiatan diskusi selama proses pembelajaran. Hal ini sejalan dengan penelitian Noma dkk., bahwa kemampuan menganalisis (C4) melalui kegiatan mengidentifikasi fenomena yang dihadirkan dan merumuskan pertanyaan (Noma \& Prayitno, 2016). Kemampuan mengevaluasi (C5) melalui kegiatan memeriksa dan mengkritik ketika peserta didik melaporkan hasil penemuan yang telah dilakukan kepada masing-masing anggota kelompok dalam kegiatan diskusi. Melalui kegiatan mengevaluasi proses pencarian solusi permasalahan dan meningkatkan kemampuan mencipta (C6) melalui kegiatan penarikan kesimpulan, telah menumbuhkan keterampilan berpikir tingkat tinggi siswa.

LKS Inkuiri berbasis Keterampilan berpikir tingkat tinggi, melatih siswa mengemukakan ide-ide inovatif dan orisinil yang dituangkan dalam menganalisis masalah, memberikan jawaban sementara (hipotesis) terhadap masalah yang diangkat, menyusun rencana investigasi maupun dalam melaksanakan investigasi guna memecahkan masalah-masalah, dan menyajikan data (Arnyana, 2006). Langkah-langkah kegiatan tersebut dapat menumbuhkan keterampilan berpikir tingkat tinggi siswa berdasarkan indikator yaitu menganalisis, mengevaluasi, dan mencipta. Sesuai (King, Goodson, \& Rohani, 1998), bahwa Keterampilan berpikir tingkat tinggi (Higher Order Thinking Skill) atau HOTS memberikan siswa keterampilan hidup yang relevan dan memfasilitasi membangun pengetahuannya. Terlihat ketika siswa mendemonstrasikan keterampilan dan mengkomunikasikan pemahamannya secara baik dan mendalam. Siswa akan dapat membedakan ide atau gagasan secara jelas, berargumen dengan baik, mampu memecahkan masalah, mampu mengkonstruksi penjelasan, mampu berhipotesis dan memahami hal-hal 
kompleks menjadi lebih jelas (Suryawati et al., 2015).

Pembelajaran dengan menggunakan LKS model inkuiri pada materi Suhu dan Kalor terbukti efektif untuk menumbuhkan keterampilan berpikir tingkat tinggisiswa. Sejalan dengan penelitian Afcariono, (2008) bahwa pembelajaran inkuiri dapat mengembangkan kemampuan berpikir tingkat tinggi.

\section{SIMPULAN DAN SARAN Simpulan}

Berdasarkan hasil penelitian dan pembahasan, disimpulkan bahwa LKS berbasis inkuiri efektif untuk menumbuhkan keterampilan berpikir tingkat tinggi siswa. Efektivitas LKS berbasis ketrampilan berpikir tingkat tinggi terbukti berpengaruh dengan kategori sedang untuk menumbuhkan keterampilan berpikir tingkat tinggi, berdasarkan perolehan hasil uji effect size.

\section{Saran}

Berdasarkan hasil penelitian disarankan kepada pendidik lain menggunakan LKS dengan model Inkuiri untuk menumbuhkan keterampilan berpikir tingkat tinggi siswa. LKS dengan model Inkuiri memerlukan pengelolahan sebaik-baiknya agar proses dalam pembelajaran menggunakan LKS ini mendapatkan hasil yang optimal, serta penerapan LKS hendaknya dilakukan sesuai dengan prosedur.

\section{DAFTAR PUSTAKA}

Abdurrahman, A. (2016). Pemanfaatan Science In Box dalam Pembelajaran Berbasis Inkuiri di SMP untuk Meningkatkan Penguasaan Konsep Fluida Statis. Jurnal Ilmiah Pendidikan Fisika Al-Biruni, 5(2), 205-212.

https://doi.org/10.24042/jpifalbiruni. v5i2.120

Arifin, Z. (2017). Mengembangkan
Instrumen Pengukur Critical Thinking Skills Siswa pada Pembelajaran Matematika Abad 21. Jurnal THEOREMS (The Original Research of Mathematics), 1(2), 92100.

Arnyana, I. B. P. (2006). Pengaruh Penerapan Strategi Pembelajaran Inovatif pada Pelajaran Biologi Terhadap Kemampuan Berpikir Kreatif Siswa SMA. Jurnal Pendidikan Dan Pengajaran IKIP Negeri Singaraja, (3), 496-515.

BNSP. (2006). Panduan Penyusunan Kurikulum Tingkat Satuan Pendidikan Jenjang Pendidikan Dasar dan Menengah Badan Standar Nasional Pendidikan 2006, 1-23.

Crespo, M. Á. G., \& Pozo, J. I. (2004). Relationships between everyday Knowledge and Scientific Knowledge: Understanding how matter Changes. International Journal of Science Education, 26(11), 1325-1343. https://doi.org/10.1080/09500690420 00205350

Damayanti, D. S., Ngazizah, N., \& Setyadi K, E. (2013). Pengembangan Lembar Kerja Siswa ( LKS ) dengan Pendekatan Inkuiri Terbimbing untuk Mengoptimalkan Kemampuan Berpikir Kritis Peserta Didik pada Materi Listrik Dinamis SMA Negeri 3 Purworejo Kelas X Tahun Pelajaran 2012 / 2013. Radiasi, 3(1), 58-62.

Erlinda, N. (2016). Penerapan Metode Pembelajaran Inkuiri Disertai Handout: Dampak terhadap Hasil Belajar Fisika Siswa SMAN 1 Batang Anai Padang Pariaman. Jurnal Ilmiah Pendidikan Fisika AlBiruni, 5(2), 223-231. https://doi.org/10.24042/jpifalbiruni. v5i2.122

Ertikanto, C. (2014). Kemampuan Sciencetific Inquiri Guru Sekolah Dasar dalam Perkuliahan 
Pembelajaran IPA-SD. Jurnal Pendidikan MIPA, 15(1), 64-70.

Hake, R. R. (2002). Relationship of individual student normalized learning gains in mechanics with gender, high-school physics, and pretest scores on Mathematics and Spatial Visualization. Physics Education Research Conference, 114.

Hopson, M. H., Simms, R. L., \& Knezek, G. A. (2001). Using a technologyenriched environment to improve higher-order thinking skills. Journal of Research on Technology in Education, 34(2), 109-119. https://doi.org/10.1080/15391523.20 01.10782338

Huck, S. (2012). Reading Statistics and Research. Knoxville: University of Tennessee.

Jayanti, R. D., Romlah, R., \& Saregar, A. (2016). Efektivitas Pembelajaran Fisika Model Problem Based Learning (PBL) melalui Metode POE terhadap Kemampuan Berpikir Tingkat Tinggi Peserta Didik. In Seminar Nasional Pendidikan (pp. 208-214). Bandar Lampung: Program Studi Pendidikan Fisika Universitas Lampung.

Karsli, F., \& Şahin, Ç. (2009). Developing Worksheet Based on Science Process Skills: Factors Affecting Solubility. Asia-Pacific Forum on Science Learning and Teaching, 10(1), 1-12.

King, F. J., Goodson, L., \& Rohani, F. (1998). Higher Order Thinking Skills. Publication of the Educational Services Program, Now Known as the Center for Advancement of Learning and Assessment. Obtido de: Www.cala.fsu.edu, 1-176.

Kostelníková, M., \& Ožvoldová, M. (2013). Inquiry in Physics Classes by Means of Remote Experiments. Procedia - Social and Behavioral
Sciences, $\quad 89, \quad 133-138$. https://doi.org/10.1016/j.sbspro.2013 .08 .822

Kristianingsih, D. (2010). Peningkatan Hasil Belajar Siswa Melalui Model Pembelajaran Inkuiri dengan Metode Pictorial Riddle pada Pokok Bahasan Alat-Alat Optik di SMP. Jurnal Pendidikan ..., 6(1), 10-13.

Lailly, N. R., \& Wisudawati, A. W. (2015). Analisis Soal Tipe Higher Order Thinking Skill ( HOTS ) dalam Soal UN Kimia SMA Rayon B Tahun 2012 / 2013. Kaunia, XI(1), 27-39.

Lee, C.-D. (2014). Worksheet Usage, Reading Achievement, Classes' Lack of Readiness, and Science Achievement: A Cross-Country Comparison. International Journal of Education in Mathematics, Science and Technology, 2(2), 96106.

Lindawati, L., Saregar, A., \& Yuberti, Y. (2016). Pengembangan Instrumen Authentic Assessment untuk Mengukur Higher Order Thinking Skills Peserta Didik. In Seminar Nasional Pendidikan (pp. 140-149). Bandar Lampung: Program Studi Pendidikan Fisika Universitas Lampung.

National Education Association. (2014). Preparing 21st Century Students for a Global Society: An Educator' $s$ Guide to the "Four Cs ."

Noma, L. D. W. I., \& Prayitno, B. A. D. I. (2016). Penerapan Model Problem Based Learning ( PBL ) pada Materi Pencemaran Lingkungan untuk Meningkatkan Kemampuan Berpikir Tingkat Tinggi Peserta Didik Kelas $X$ MIA 3 SMA Negeri 2 Sukoharjo Tahun Pelajaran 2015 / 2016. BIOPEDAGOGI, 5(2), 15-20.

Özmen, H., \& Yildrim, N. (2005). Effect of Work Sheets on Student ' S Success: Acids and Bases Sample. Journal of Turkish Science 
Education, 2(2), 2-5.

Rofiah, E., Aminah, N. S., \& Ekawati, E. Y. (2013). Penyusunan Instrumen Tes Kemampuan Berpikir Tingkat Tinggi Fisika pada Siswa SMP. Jurnal Pendidikan Fisika Universitas Sebelas Maret, 1(2), 1722.

Rohaniawati, D. (2016). Penerapan Pendekatan Pakem untuk Meningkatkan Keterampilan Berpikir Mahasiswa dalam Mata Kuliah Pengembangan Kepribadian Guru. Tadris: Jurnal Keguruan Dan Ilmu Tarbiyah, 1(2), 155-172.

Rustaman, N. Y. (2011). Pendidikan dan Penelitian Sains dalam Mengembangkan Keterampilan Berpikir Tingkat Tinggi untuk Pembangunan Karakter. In Seminar Nasional VIII Pendidikan Biologi (pp. 139-144).

Saregar, A. (2016). Pembelajaran Pengantar Fisika Kuantum Dengan Memanfaatkan Media Phet Simulation Dan Lkm Melalui Pendekatan Saintifik: Dampak Pada Minat Dan Penguasaan Konsep Mahasiswa. Jurnal Ilmiah Pendidikan Fisika Al-Biruni, 5(1), 53-60.

Saregar, A., Latifah, S., \& Sari, M. (2016). Efektivitas Model Pembelajaran CUPs: Dampak terhadap Kemampuan Berpikir Tingkat Tinggi Peserta Didik Madrasah Aliyah Mathla'ul Anwar Gisting Lampung. Jurnal Ilmiah Pendidikan Fisika Al-Biruni, 5(2), 233-243.

https://doi.org/10.24042/jpifalbiruni. v5i2.123

Suryawati, E., Hamzah, A., \& Hayati, E. (2015). Pengembangan Lembar Kerja Siswa Biologi SMA Berbasis Pendekatan Ilmiah untuk Meningkatkan Keterampilan Berfikir Siswa. Jurnal Pendidikan Biologi, 6(2), 91-99.
Susantini, E., Isnawati, \& Lisdiana, L. (2016). Effectiveness of Genetics Student Worksheet to Improve Creative Thinking Skills of Teacher Candidate Students. Journal of Science Education, 17(2), 74-79.

Trewet, C. L. B., \& Fjortoft, N. (2013). Evaluation of the Impact of A Continuing Professional Development Worksheet on Sustained Learning and Implementing Change after A Continuing Pharmacy Education Activity. Research in Social and Administrative Pharmacy, 9(2), 215221.

https://doi.org/10.1016/j.sapharm.20 12.06.002

Trianto. (2010). Model Pembelajaran Terpadu: Konsep, Strategi, dan Implementasinya dalam Kurikulum Tingkat Satuan Pendidikan (KTSP). Jakarta: Bumi Aksara.

Wati, W., \& Fatimah, R. (2016). Effect Size Model Pembelajaran Kooperatif Tipe Numbered Heads Together (NHT) terhadap Kemampuan Berpikir Kritis Siswa pada Pembelajaran Fisika. Jurnal Ilmiah Pendidikan Fisika Al-Biruni, 5(2), 213-222.

https://doi.org/10.24042/jpifalbiruni. v5i2.121

Widodo, T., \& Kadarwati, S. (2013). Higher Order Thinking Berbasis Pemecahan Masalah untuk Meningkatkan Hasil Belajar Berorientasi Pembentukan Karakter Siswa. Jurnal Cakrawala Pendidikan, 5(1), 161-171. https://doi.org/10.21831/CP.V5I1.12 69

Wykes, T., Huddy, V., Cellard, C., McGurk, S. R., Czobor, P., Craufurd, D., ... Paulsen, J. S. (2011). A MetaAnalysis of Cognitive Remediation for Schizophrenia: Methodology and Effect Sizes. American Journal of Psychiatry, 168(5), 472-485. 
https://doi.org/10.1176/appi.ajp.2010 .10060855

Yonata, Khofifatin, dan B. (2013). Ketuntasan Belajar Siswa dalam Berpikir Tingkat Tinggi pada Materi Pokok Larutan Asam Basa Kelas XI SMA Negeri 1 Gedangan Sidoarjo dengan Menerapkan Model Pembelajaran Inkuiri. UNESA Journal of Chemical Education,
2(2), 51-56.

Yuliati, L. (2013). Efektivitas Bahan Ajar IPA Terpadu terhadap Kemampuan Berpikir Tingkat Tinggi Siswa SMP. Jurnal Pendidikan Fisika Indonesia (Indonesian Journal of Physics Education), 9(1), 53-57.

Yusufhadi, M. (2004). Menyemai Benih Teknologi Pendidikan. Jakarta: Pranada Media. 